Article

\title{
The Prognostic Impact of Comorbidities in Patients with De-Novo Diffuse Large B-Cell Lymphoma Treated with R-CHOP Immunochemotherapy in Curative Intent
}

\author{
Florian Kocher ${ }^{1}$, Michael Mian ${ }^{2,3}$, Andreas Seeber $^{1}{ }^{\mathbb{D}}$, Michael Fiegl $^{1}$ and \\ Reinhard Stauder $1, *$ (D) \\ 1 Department of Internal Medicine V (Hematology and Oncology), Innsbruck Medical University, \\ 6020 Innsbruck, Austria; florian.kocher@i-med.ac.at (F.K.); andreas.seeber@tirol-kliniken.at (A.S.); \\ m.fiegl@pk-hochrum.com (M.F.) \\ 2 Department of Hematology \& CBMT, Central Hospital of Bolzano (SABES-ASDAA), 39100 Bolzano-Bozen, \\ Italy; m.mian@med-sci.eu \\ 3 Riga Stradinš University, 1007 Riga, Latvia \\ * Correspondence: reinhard.stauder@i-med.ac.at; Tel.: +43-512504-82440; Fax: +43-512504-2630
}

Received: 21 March 2020; Accepted: 31 March 2020; Published: 2 April 2020

check for updates

\begin{abstract}
Background: Patient-related factors, namely comorbidities, impact the clinical outcome of patients with diffuse large B-cell lymphoma (DLBCL). Methods: The prevalence and prognostic impact of comorbidities were examined using the validated scores Charlson Comorbidity Index (CCI) and Hematopoietic Cell Transplantation-specific Comorbidity Index (HCT-CI) in 181 patients with DLBCL at initial diagnosis before treatment with rituximab, cyclophosphamide, vincristine, doxorubicin and prednisone (R-CHOP). Results: Pronounced comorbidities as defined by CCI and HCT-CI scoring of $\geq 2$ were detected in $9.9 \%$ and $28.2 \%$ of patients, respectively, and occurred more frequently at advanced age $(p<0.001)$. Higher CCI scoring was associated with lower complete response rate $(p=0.020)$. Both advanced CCI and HCT-CI were significantly associated with shortened overall survival (3-year OS: CCI $\geq 2$ vs. $0-1,38.9 \%$ vs. $81.3 \%, p<0.001$; HCT-CI $\geq 2$ vs. $0-1,56.9 \%$ vs. $84.9 \%$, $p<0.001)$. Both comorbidity scores remained independent risk factors in the multivariate analysis (HCT-CI $\geq 2$ HR: 2.6, $p=0.004 ; \mathrm{CCI} \geq 2$ HR: 3.6, $p=0.001$ ). Conclusion: This study demonstrates the prognostic relevance of comorbidities classified by CCI and HCT-CI in patients with DLBCL undergoing curative treatment with R-CHOP. A structured evaluation of comorbidities might refine prognostication alongside currently used prognostic parameters, namely age, and should be evaluated in prospective trials.
\end{abstract}

Keywords: comorbidities; HCT-CI; CCI; DLBCL; prognosis; R-CHOP

\section{Introduction}

Diffuse large B cell lymphoma (DLBCL) accounts for approximately 25-30\% of all types of non-Hodgkin lymphomas (NHL), thus representing the most common histological subtype [1]. The clinical course of the disease is heterogeneous and is affected by various parameters including comorbidities, malnutrition, impaired functional capacities and reduced resilience and organ reserve [2-4]. The International Prognostic Index (IPI) was devised to predict the survival of patients with DLBCL. As the IPI classification was developed in the pre-rituximab era, when predominantly patients below the age of 60 were eligible for intensified treatment regimens, the cutoff for age as a risk factor was set at 60 years [5]. However, with the introduction of rituximab, the treatment of NHL has changed substantially and outcome has improved markedly. Several large trials have shown improved survival 
in DLBCL patients $>60$ years using the combination of rituximab, cyclophosphamide, vincristine, doxorubicin and prednisone (R-CHOP) [6-10]. Moreover, the broad availability of granulocyte colony-stimulating factor (G-CSF) has facilitated comparable dose intensities in both older and younger patients [11]. Consequently, guidelines recommend this immune-chemotherapy, even in selected subgroups of patients at advanced age $[4,12]$. As a consequence of new treatment options and to enhance the prognostic impact, modifications of the IPI have been established including the R-IPI and the NCCN-IPI $[13,14]$. Nevertheless, the original IPI is still widely used to evaluate prognosis in DLBCL.

The prognostic parameters of the IPI consider the biology and the stage of the malignant disorder, as well as the age and the performance status of patients. Recently, the relevance of patientrelated factors, namely comorbidities, were recognized as important parameters for prognostication and decision-making. Therefore, the integration of comorbidity scores into clinical practice has been suggested [12]. Comorbidities represent competing adverse risk factors and affect treatment decision-making in patients since they can preclude the use of certain drugs or require a dose reduction that may lead to a dismal outcome [15]. Several validated scores for assessing comorbidities have been reported in the literature so far [16]. The Charlson Comorbidity Index (CCI) was originally developed to elaborate the prognostic significance of comorbidities irrespectively of the underlying disease [17]. This score has also been used to estimate the comorbidity burden in cancer patients [18], including DLBCL [19-22]. The Hematopoietic Cell Transplantation-specific Comorbidity Index (HCT-CI) was developed to evaluate the feasibility and the risk of patients undergoing intensive therapy and hematopoietic stem cell transplantation (HSCT) [23-26]. However, the clinical relevance of the HCT-CI in patients not undergoing HSCT is still a matter of debate and this score has so far not been evaluated in DLBCL patients treated with R-CHOP.

The goal of this study was to analyze the prognostic impact of the comorbidity burden as defined by the CCI and the HCT-CI in real-life in a homogeneous cohort of consecutive DLBCL patients treated at a single institution.

\section{Methods}

\subsection{Patients and Methods}

Between October 2000 and November 2012, 181 consecutive patients newly diagnosed with DLBCL and treated in first line in curative intent with full dose R-CHOP at the Medical University of Innsbruck were included in this study. Parameters included were baseline characteristics, treatment-related variables and clinical outcome. While the clinical data and the outcome of this cohort of patients have already been published [27,28], the present analysis focuses on the prevalence and clinical impact of distinct comorbidities at initial diagnosis. The burden and prognostic impact of comorbidities were evaluated with two validated comorbidity scores that were retrospectively assessed using the patients' charts. A detailed description of these scores including definitions and grading of comorbidities is provided elsewhere $[17,23]$. An elevated comorbidity score was defined as either CCI $\geq 2$ or HCT-CI $\geq 2$.

\subsection{Statistics}

The Chi-square test was performed to assess the significance of differences between categorical variables. Response was assessed with CT or PET-CT applying the international response criteria for NHL $[29,30]$. Overall survival (OS) was plotted as a curve using the Kaplan-Meier method. The Log-rank test was employed to assess the impact of categorical variables on survival. Multivariate analyses were done according to the Cox regression and the binary logistic regression method. A receiver operating characteristics (ROC) analysis was employed to elaborate the discriminative power of both comorbidity scores. Distributions were compared with the Wilcoxon-Mann-Whitney test. A $p$-value of $<0.05$ was considered statistically significant. All statistical analyses were performed with the Statistical Package for the Social Sciences (SPSS) software, version 20.0 (IBM, Armonk, NY, USA). The study was approved by the Ethics Committee of the Medical University of Innsbruck. 


\section{Results}

\subsection{Clinical Characteristics}

Altogether, 181 consecutive patients with newly diagnosed DLBCL were included in this analysis. Median age at diagnosis was 60 (SD 16.4) years. Median time between diagnosis and start of treatment with R-CHOP was 16 days (interquartile range 9-28). Of the 181 included patients 85 (47.0\%) were female. An IPI $\geq 3$ was recorded in 63 (42.6\%) of 148 evaluable patients. In total, $96.1 \%$ of patients received at least four cycles of R-CHOP. Complete response (CR) on first-line R-CHOP was achieved in $135(74.6 \%)$ patients. A relapse was observed in $53(30.5 \%)$ of 174 patients (Table 1$)$.

Table 1. Clinical characteristics.

\begin{tabular}{|c|c|c|}
\hline & Valid Cases $n$ & Clinical Characteristics $n(\%)$ \\
\hline \multicolumn{3}{|l|}{ Baseline characteristics } \\
\hline Total number & 181 & 100 \\
\hline Median age (range), years & & $60(18-90)$ \\
\hline Women & 181 & $85(47.0)$ \\
\hline Age $\geq 60$ years & & $91(50.3)$ \\
\hline B-symptoms & 156 & $65(41.7)$ \\
\hline Ann Arbor Stage & 181 & \\
\hline $\mathrm{I}$ & & $29(16.0)$ \\
\hline II & & $51(28.2)$ \\
\hline III & & $40(22.1)$ \\
\hline IV & & $61(33.7)$ \\
\hline$>1$ Extranodal site & 172 & $52(30.2)$ \\
\hline WHO Performance Status $\geq 2$ & 155 & $37(23.9)$ \\
\hline $\mathrm{LDH}>\mathrm{UNL}$ & 160 & $91(56.9)$ \\
\hline $\mathrm{IPI} \geq 3$ & 148 & $63(42.6)$ \\
\hline $\begin{array}{l}\text { Lymphadenopathy }>5 \mathrm{~cm} \text { and/or } \\
\text { Maximum spleen diameter } \geq 20 \mathrm{~cm}\end{array}$ & 166 & $77(46.4)$ \\
\hline \multicolumn{3}{|l|}{ Treatment } \\
\hline 1 cycle R-CHOP & 178 & $2(1.1)$ \\
\hline 2 cycles R-CHOP & & $2(1.1)$ \\
\hline 3 cycles R-CHOP & & $3(1.7)$ \\
\hline 4 cycles $\mathrm{R}-\mathrm{CHOP}$ & & $6(3.4)$ \\
\hline 5 cycles $\mathrm{R}-\mathrm{CHOP}$ & & $7(3.9)$ \\
\hline$\geq 6$ cycles $\mathrm{R}-\mathrm{CHOP}$ & & $158(88.8)$ \\
\hline Response & 181 & \\
\hline CR & & $135(74.6)$ \\
\hline PR & & $16(8.8)$ \\
\hline SD & & $1(0.6)$ \\
\hline PD & & $20(11.0)$ \\
\hline Interruption & & $3(1.7)$ \\
\hline Death & & $5(2.8)$ \\
\hline Unknown & & $1(0.6)$ \\
\hline Relapses & 174 & $53(30.5)$ \\
\hline
\end{tabular}




\subsection{Charlson Comorbidity Index}

Based on CCI criteria $76.8 \%$ of the patients $(n=139)$ did not reveal any comorbidities. $13.3 \%$ had one index point and $9.9 \%$ had an index $\geq 2$. The most prevalent comorbid conditions were chronic obstructive pulmonary disease, diabetes without complications and a secondary non-metastatic tumor (Table 2).

Table 2. Comorbidities as defined by the Charlson Comorbidity Index (CCI).

\begin{tabular}{|c|c|c|}
\hline Charlson Comorbidity Index & Scoring Points & $\begin{array}{c}\text { Comorbidities According } \\
\text { to the CCI } n(\%)\end{array}$ \\
\hline Second solid tumor (non-metastatic) & 2 & $7(3.9)$ \\
\hline Diabetes (without complication) & 1 & $7(3.9)$ \\
\hline Chronic pulmonary disease & 1 & $7(3.9)$ \\
\hline Connective tissue disease & 1 & $6(3.3)$ \\
\hline Congestive heart failure & 1 & $4(2.2)$ \\
\hline Peripheral vascular disease & 1 & $4(2.2)$ \\
\hline Cerebrovascular disease (except hemiplegia) & 1 & $4(2.2)$ \\
\hline Ulcer disease & 1 & $4(2.2)$ \\
\hline Diabetes with end organ damage & 2 & $3(1.7)$ \\
\hline Myocardial infarction & 1 & $2(1.1)$ \\
\hline Moderate or severe liver disease & 3 & $2(1.1)$ \\
\hline Mild liver disease & 1 & $1(0.6)$ \\
\hline Hemiplegia & 2 & $1(0.6)$ \\
\hline Moderate or severe renal disease & 2 & - \\
\hline Dementia & 1 & - \\
\hline Leukemia & 2 & - \\
\hline Lymphoma & 2 & - \\
\hline Acquired immunodeficiency syndrome & 6 & - \\
\hline Second solid tumor (metastatic) & 6 & - \\
\hline \multicolumn{3}{|l|}{ Charlson Comorbidity Scoring points } \\
\hline CCI 0 & & $139(76.8)$ \\
\hline CCI 1 & & $24(13.3)$ \\
\hline $\mathrm{CCI} 2$ & & $13(7.2)$ \\
\hline CCI 3 & & $3(1.7)$ \\
\hline CCI 4 & & $2(1.1)$ \\
\hline
\end{tabular}

\subsection{Hematopoietic Cell Transplantation-Specific Comorbidity Index}

According to the HCT-CI, $64.1 \%(n=116)$ of the patients presented without comorbidities, whereas in $7.7 \%(n=14)$ one index point was observed. The remaining $28.2 \%(n=51)$ of the patients had at least two HCT-CI points. The most prevalent comorbidities were a history of a previous solid tumor and cardiovascular comorbidities (Table 3). 
Table 3. Comorbidities as defined by the Haematopoetic Cell Transplantation-specific Comorbidity Index (HCT-CI).

\begin{tabular}{|c|c|c|}
\hline HCT Comorbidity Index & Scoring Points & $\begin{array}{c}\text { Comorbidities According to } \\
\text { the HCT-CI } n(\%)\end{array}$ \\
\hline Previous solid tumor & 3 & $17(9.4)$ \\
\hline Cardiovascular comorbidity & 1 & $13(7.2)$ \\
\hline Renal comorbidity & 2 & $12(6.6)$ \\
\hline Diabetes & 1 & $10(5.5)$ \\
\hline Arrhythmia & 1 & $10(5.5)$ \\
\hline Rheumatologic comorbidity & 2 & $6(3.3)$ \\
\hline Heart valve disease & 3 & $5(2.8)$ \\
\hline Psychiatric disturbance & 1 & $5(2.8)$ \\
\hline Cerebrovascular disease & 1 & $4(2.2)$ \\
\hline Pulmonary comorbidity moderate & 2 & $4(2.2)$ \\
\hline Peptic ulcer & 2 & $4(2.2)$ \\
\hline Obesity & 1 & $3(1.7)$ \\
\hline Severe liver disease & 3 & $2(1.1)$ \\
\hline Pulmonary comorbidity severe & 3 & $1(0.6)$ \\
\hline Mild liver disease & 1 & $1(0.6)$ \\
\hline Inflammatory bowel disease & 1 & - \\
\hline Infection & 1 & - \\
\hline \multicolumn{3}{|l|}{ HCT-CI Scoring points $\geq 2$} \\
\hline HCT-CI 0 & & $116(64.1)$ \\
\hline HCT-CI 1 & & $14(7.7)$ \\
\hline HCT-CI 2 & & $23(12.7)$ \\
\hline HCT-CI 3 & & $16(8.8)$ \\
\hline HCT-CI 4 & & $6(3.3)$ \\
\hline HCT-CI 5 & & $1(0.6)$ \\
\hline HCT-CI 6 & & - \\
\hline HCT-CI 7 & & $4(2.2)$ \\
\hline HCT-CI 8 & & $1(0.6)$ \\
\hline
\end{tabular}

\subsection{Association between Comorbidities and Clinical Characteristics}

Advanced age was significantly associated with an increased burden of comorbidities: in patients $<50$ years a $\mathrm{CCI} \geq 2$ and a HCT-CI $\geq 2$ were recorded in $1.9 \%$ and $7.5 \%$ of patients, whereas in individuals $\geq 70$ years the prevalence was $22.6 \%$ and $47.2 \%$, respectively $(p<0.001)$ (Figure 1$)$. In a binary logistic regression model including the parameters of the IPI, only age was significantly associated with a $\mathrm{CCI} \geq 2(p=0.006)$ and a HCT-CI $\geq 2(p=0.001)$.

The number of administered R-CHOP cycles was comparable between groups with low vs. high comorbidities: ( $\geq 4$ treatment cycles; HCT-CI: $96.9 \%$ vs. $94.0 \%, p=0.403$; CCI: $96.6 \%$ vs. $88.9 \%$, $p=0.150$ ). Likewise, time between diagnosis and treatment start was comparable between the two comorbidity groups (HCT-CI: $p=0.474$; CCI: $p=0.686$ ). Duration of R-CHOP treatment, which might be considered a surrogate for dose-density, was similar in patients with CCI $<2$ and CCI $\geq 2$ $(p=0.359)$. When patients were broken down according to HCT-CI, a trend towards prolonged treatment duration was observed for the HCT-CI $\geq 2$ group $(p=0.092)$. The complete remission $(\mathrm{CR})$ rate was $77.3 \%$ in patients with $\mathrm{CCI}<2$, whereas the $\mathrm{CR}$ rate was $50.0 \%$ in patients with $\mathrm{CCI} \geq 2$ 
$(p=0.020)$. The CR rate in the HCT-CI groups was $78.5 \%$ and $64.7 \%$ in HCT-CI $<2$ and HCT-CI $\geq$ 2 patients, respectively $(p=0.061)$ (Supplementary Table S1). With regard to relapse-free survival, defined as time from diagnosis until disease relapse, no significant differences were observed (CCI $<2$ vs. $\mathrm{CCI} \geq 2$ : 10.4 vs. 6.9 years, $p=0.642$; HCT-CI $<2$ vs. $\mathrm{HCT}-\mathrm{CI} \geq 2$ : 10.2 vs. 9.9 years, $p=0.246$ ). At final analysis median OS had not been reached: 3-year and 5-year OS rates were $76.6 \%$ and $74.0 \%$, respectively. All parameters of IPI, the number of administered treatment cycles as well as the response to R-CHOP were significantly associated with OS in univariate analysis (Table 4). Most importantly, high comorbidity burden as assessed by both scores, represented an adverse prognostic factor. Patients with a CCI score of $0-1$ had a 3-year OS rate of $81.3 \%$, whereas this percentage was significantly lower in patients with $\mathrm{CCI} \geq 2: 38.9 \%(p<0.001)$ (Table 4$)$. Likewise, the 3 -year OS rate was $84.9 \%$ and $56.9 \%$ in patients with $0-1$ and $\geq 2$ in HCT-CI, respectively $(p<0.001)$ (Table 4 and Figure 2$)$. In an exploratory ROC analysis to predict death, both comorbidity scores showed a comparable discriminative power (HCT-CI: AUC 0.654, 95\%CI 0.56-0.75, $p=0.002$; CCI: AUC 0.657, 95\%CI 0.56-0.75, $p<0.001$ ).

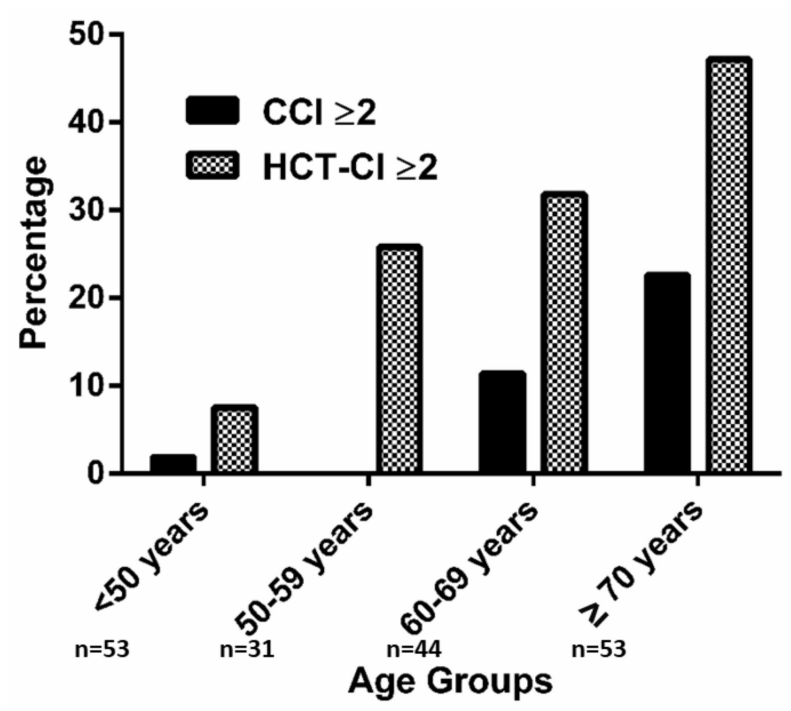

Figure 1. Prevalence of HCT-CI and CCI $\geq 2$ according to age groups. Prevalence rates according to age groups: $<50$ years: $\mathrm{CCI} \geq 2,1.9 \% \mathrm{HCT}-\mathrm{CI} \geq 2,7.5 \%$; $50-59$ years: $\mathrm{CCI} \geq 2,-\mathrm{HCT}-\mathrm{CI} \geq 2,25.8 \%$; 60-69 years: $\mathrm{CCI} \geq 2,11.4 \% \mathrm{HCT}-\mathrm{CI} \geq 2,31.8 \%$; $\geq 70$ years: $\mathrm{CCI} \geq 2,22.6 \mathrm{HCT}-\mathrm{CI} \geq 2,47.2 \%$.

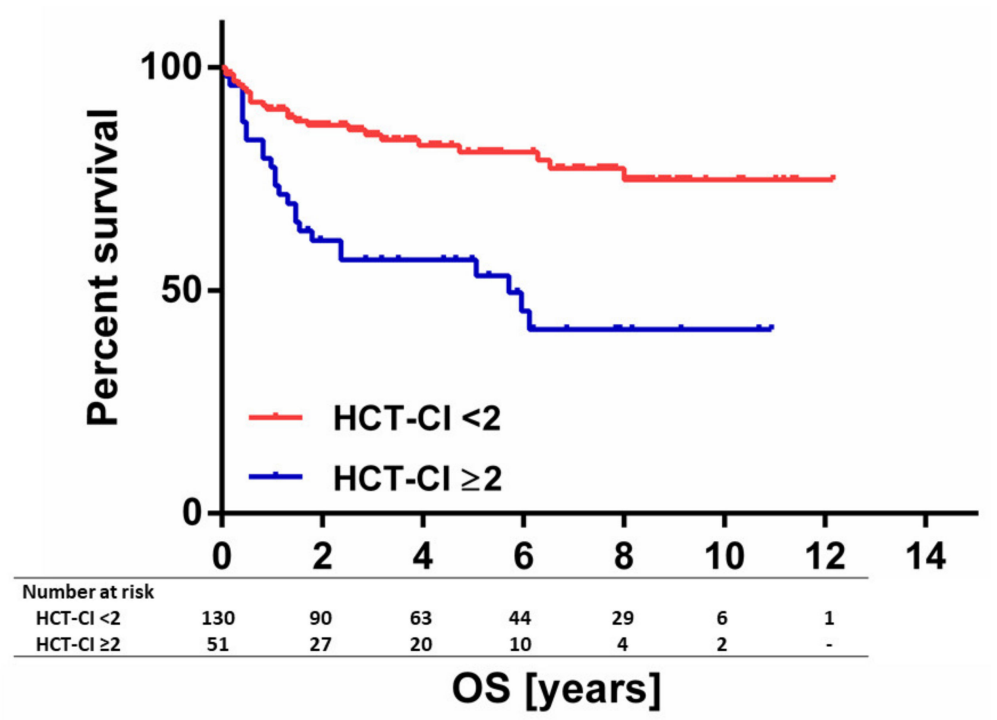

Figure 2. Overall survival according to HCT-CI. 3-year and 5-year OS was $84.9 \%$ and $81.0 \%$ in patients with an HCT-CI of $0-1$. 3-year and 5-year OS was $56.8 \%$ and $56.8 \%$ in patients with an HCT-CI of $\geq 2$. 
Table 4. Prognostic factors for overall survival in univariate analyses.

\begin{tabular}{|c|c|c|c|c|}
\hline & \multirow[b]{2}{*}{$\begin{array}{c}\text { Valid Cases } \\
n\end{array}$} & \multicolumn{3}{|c|}{ Overall Survival } \\
\hline & & 3-Year OS (\%) & 5-Year OS (\%) & $p$ Value \\
\hline Whole cohort & 181 & 76.6 & 74.0 & - \\
\hline \multicolumn{5}{|l|}{ Baseline characteristics } \\
\hline \multicolumn{5}{|l|}{ Gender } \\
\hline Male & 96 & 81.3 & 78.1 & 0.112 \\
\hline Female & 85 & 72.8 & 69.0 & \\
\hline \multicolumn{5}{|l|}{ Age * } \\
\hline Age $<60$ years & 90 & 84.4 & 82.3 & $<0.001$ \\
\hline Age $\geq 60$ years & 91 & 69.0 & 65.8 & \\
\hline \multicolumn{5}{|l|}{ Ann Arbor Stage* } \\
\hline I-II & 80 & 90.9 & 90.9 & $<0.001$ \\
\hline III-IV & 101 & 64.7 & 59.6 & \\
\hline \multicolumn{5}{|l|}{$\mathrm{LDH}^{*}$} \\
\hline Normal & 69 & 90.9 & 88.9 & $<0.001$ \\
\hline$>\mathrm{UNL}$ & 91 & 67.6 & 64.4 & \\
\hline \multicolumn{5}{|l|}{ WHO Performance } \\
\hline \multicolumn{5}{|l|}{ Status * } \\
\hline $0-1$ & 118 & 82.6 & 80.0 & $<0.001$ \\
\hline$\geq 2$ & 37 & 57.8 & 57.8 & \\
\hline \multicolumn{5}{|l|}{ Extranodal sites * } \\
\hline $0-1$ & 120 & 82.2 & 79.8 & 0.040 \\
\hline$\geq 2$ & 52 & 63.3 & 59.6 & \\
\hline \multicolumn{5}{|l|}{ IPI } \\
\hline$<3$ & 85 & 91.2 & 89.4 & $<0.001$ \\
\hline$\geq 3$ & 63 & 56.4 & 53.7 & \\
\hline \multicolumn{5}{|l|}{ Treatment } \\
\hline$\geq 4$ cycles $\mathrm{R}-\mathrm{CHOP}$ & 7 & 33.3 & 33.3 & $<0.001$ \\
\hline$<4$ cycles $\mathrm{R}-\mathrm{CHOP}$ & 171 & 78.1 & 75.4 & \\
\hline \multicolumn{5}{|l|}{ Response } \\
\hline CR or PR & 151 & 88.1 & 85.1 & $<0.001$ \\
\hline Other & 30 & 8.2 & 8.2 & \\
\hline \multicolumn{5}{|l|}{$\mathrm{CCI}^{*}$} \\
\hline $0-1$ & 163 & 81.3 & 78.3 & $<0.001$ \\
\hline$\geq 2$ & 18 & 38.9 & 38.9 & \\
\hline \multicolumn{5}{|l|}{ HCT-CI * } \\
\hline $0-1$ & 130 & 84.9 & 81.0 & $<0.001$ \\
\hline$\geq 2$ & 51 & 56.8 & 56.8 & \\
\hline
\end{tabular}

* parameters included in multivariate analyses.

As can be seen in Table 4, extranodal site, performance status $\geq 2$, age $\geq 60$ years and both comorbidity scores were included in two Cox-proportional hazard models $(n=136)$. In both multivariate models, advanced stage at diagnosis ( $\geq \mathrm{III}$ ), performance status $\geq 2$ and either HCT-CI or $\mathrm{CCI} \geq 2$ remained independent prognostic factors. Thus, HCT-CI $\geq 2$ and CCI $\geq 2$ were associated with a 2.6 (95\% CI 1.4-5.0) and a 3.6 (95\% CI 1.7-7.4) -fold increased risk for death (Table 5, Supplementary Table S2). 
Table 5. Prognostic factors for overall survival in multivariate analyses using the HCT-CI.

\begin{tabular}{lcc}
\hline & HR (95\% CI) & $p$ Value \\
\hline Ann Arbor Stage $\geq$ III & $4.3(1.8-10.6)$ & 0.001 \\
Performance Status $\geq 2$ & $2.2(1.1-4.2)$ & 0.023 \\
HCT-CI $\geq 2$ & $2.6(1.4-5.0)$ & 0.004 \\
elevated LDH & $2.1(0.8-5.2)$ & 0.129 \\
$\geq 2$ extranodal sites & $1.1(0.6-2.3)$ & 0.722 \\
age $\geq$ 60years & $2.0(0.9-4.4)$ & 0.73 \\
\hline
\end{tabular}

\section{Discussion}

To date, the IPI has represented the gold standard for prognostication in DLBCL. As a means of refining prognostic scoring the integration of comorbidities has been suggested [4]. This retrospective study aimed to assess the prevalence and the prognostic impact of comorbidity burden as defined by the validated scores CCI and HCT-CI in consecutive patients with DLBCL undergoing standard dose R-CHOP immuno-chemotherapy in curative intent.

Our cohort of patients was characterized by a relevant comorbidity burden, as highlighted by CCI scoring $\geq 2$ in $9.9 \%$. This proportion is within the range of $5.8-26 \%$ reported in retrospective series in the literature [19-21,31]. In a study focusing on patients with DLBCL at advanced age ( $\geq 75$ years) a CCI $\geq 2$ was detected in $34.9 \%$ [22], which is slightly above the prevalence of $26.7 \%$ in our subgroup [22]. This difference might be explained by the selection of patients in our cohort, who were considered to be fit to tolerate R-CHOP therapy based on evaluation by the treating physicians.

The HCT-CI was developed to better define and assess pre-existing comorbidities in hematological malignancies [23]. The better sensitivity of the HCT-CI as compared to the CCI is supported by a prevalence of $28.8 \%$ vs. $9.9 \%$ for scoring $\geq 2$ in this study. To date, there has been a lack of knowledge concerning the prevalence of HCT-CI-defined comorbidities in patients with DLBCL. In the initial description of the HCT-CI a scoring $\geq 2$ was reported in $55 \%$ of patients undergoing allogeneic HSCT [23]. The discrepancy as opposed to a lower prevalence of $28.8 \%$ in our study might be explained by different patient cohorts and the more profound diagnostic work-up prior to HSCT. For example, moderate pulmonary disease was detected in $24 \%$ of HSCT patients, whereas it was observed in only $2.2 \%$ of our cohort. While classification of pulmonary comorbidities in our study is based on grading dyspnea [23], the evaluation of patients before HSCT is generally based on more sensitive pulmonary function tests including evaluation of diffusion capacity and expiratory volume. Moreover, the lower prevalence in our study may be explained by retrospective assessment as compared to prospective analyses. In patients with NHL at advanced age ( $>70$ years) and who received autologous HSCT, a HCT-CI grade of 0 was reported in 73\% [32]. The percentage in this subgroup in our cohort was $20.7 \%$. Differences may be explained by selection criteria, as patients who were fit for HSCT were selected. In summary, our findings serve as the first benchmark, aside from HSCT, for the prevalence of HCT-CI-defined comorbidities in DLBCL.

Most importantly, an increased comorbidity burden as defined by both scores was an independent predictor of clinical outcome. The prognostic relevance of CCI in this study is in line with results from previous studies conducted in patients with DLBCL $[19,31,33,34]$. However, to the best of our knowledge this is the first study reporting the relevance of HCT-CI as a poor prognosticator in the setting of R-CHOP-treated DLBCL patients. Based on an exploratory ROC analysis, both comorbidity scores showed comparable discrimination and provide similar prognostic accuracy with regard to overall survival.

Remarkably, advanced age as dichotomized variable in accordance of the IPI definition, was a significant predictor in univariate analyses, but this association was no longer present when comorbidities were included in multivariate analyses. Additionally, the age cut-off set at 70 years failed to be an independent prognostic factor in another multivariate model. However, it has to be mentioned that age remained a significant independent prognostic factor when a model was performed with age as continuous variable. In general, age is a commonly used prognostic parameter 
in hematological malignancies $[4,12,35]$. However, a more thorough classification of patients under the aspect of prognosis was demonstrated by including parameters like physical capacity, nutritional status, and comorbidities in several studies in hematological malignancies [35]. Our findings are in line with these observations and suggest that comorbidities should be integrated in prognostic scoring. In fact, Antic et al. developed a modified NCCN-IPI by including the CCI, resulting in an increase in the prognostic value of $2.1 \%$ [36]. These findings highlight the relevance of a structured evaluation of comorbidities as an additional independent prognostic factor in DLBCL. The observations that the HCT-CI provides better accuracy in detecting comorbidities and reveals a comparative discriminative power comparable to that of the CCI may form the basis for suggesting that the HCT-CI should be integrated into combined scores.

Clinical outcome in R-CHOP-treated patients with DLBCL is associated with the administered dose intensity [37,38]. Whereas there was no difference in the number of administered therapy cycles, the response rate was significantly improved when comparing low- and high-comorbidity groups. Due to incomplete data analysis on the extent of dose-reductions as additional factor affecting response was not possible. On the other hand, relapse-free survival was not significantly inferior in patients with high comorbidity. The inferior outcome in patients with high comorbidity might be explained in part by a trend towards prolonged treatment duration, a reduced dose intensity as well as an increase in therapeutic interruptions. These findings suggest that integration of comorbidities might be helpful as a means of identifying patients at high risk for treatment toxicity as well as vulnerable patients, in whom attenuated therapy may be a more reasonable treatment option $[4,39,40]$. The finding that relapse-free survival was not associated with the burden of comorbidity, whereas it was an independent prognostic factor for OS, might reflect that patients with high comorbidities are at increased risk for other causes of death. The strength of the presented work is that it evaluates comorbidities in a well defined cohort of consecutive DLBCL patients treated homogeneously with R-CHOP in curative intent. Moreover, the unicentric design of this analysis ensures the constant validity of data evaluation. This study thus adds relevant information, as analyses published so far have often focused on the impact of comorbidities in DLBCL patients treated with various treatment regimens $[19,21,34,36]$. A weakness of this study is the retrospective evaluation of comorbidities, which may result in the underestimation of their prevalence. Moreover, the retrospective nature of the study prohibited data acquisition with regard to dose-reductions which might have been a possible reason for lower CR rates in the high comorbidity groups. Additionally, incomplete data precluded further analyses on therapy associated toxicity or death reasons. Future analyses are needed to extend these findings with a focus on prospective assessment and evaluation of both patient- and physician-reported toxicities.

Improved life expectancy will result in an increasing number of cancer patients at advanced age $[12,41]$. Thus, the prevalence of patients with comorbidities will rise dramatically over the next decades and there will be an urgent need to develop treatment algorithms in cancer patients with multiple co-existing diseases. Attenuated treatment regimens like R-miniCHOP or ofatumumabminiCHOP have already shown to provide good efficacy and safety in lymphoma patients above 80 years [42,43]. Additionally, standardized comorbidity evaluations might serve as an easy-to-use and inexpensive tool for elaborating patient prognosis and individualizing treatment decisions [44]. Integration of different domains of geriatric assessment will serve to tailor the treatment algorithms in this large group of patients irrespective of currently established age cutoffs [45].

\section{Conclusions}

In patients with DLBCL undergoing treatment with R-CHOP the burden of comorbidities, evaluated by the CCI and HCT-CI, represents an independent adverse prognosticator. Structured evaluations of comorbidities by validated scores might add important information on the prognosis of DLBCL patients aside of currently used prognostic items and should be evaluated in prospective trials. 
Supplementary Materials: The following are available online at http://www.mdpi.com/2077-0383/9/4/1005/s1, Table S1: Clinical response compared to comorbidity scoring, Table S2: Prognostic factors for overall survival in multivariate analyses using the Charlson CI.

Author Contributions: Conceptualization: F.K., M.M., M.F., R.S.; Acquisition of data: F.K., M.M., A.S., M.F.; Analysis of data: F.K., A.S.; Interpretation of data: F.K., M.M., A.S., R.S.; Preparation of manuscript: F.K., M.M., A.S., M.F., R.S. All authors have read and agreed to the published version of the manuscript.

Funding: This research received no external funding.

Conflicts of Interest: R.S.: Celgene: Honoraria, Membership in an entity's Board of Directors or advisory committees; Novartis: Honoraria, Membership in an entity's Board of Directors or advisory committees; Teva: Research funding. All other authors declare no conflict of interests.

\section{References}

1. Morton, L.M.; Wang, S.S.; Devesa, S.S.; Hartge, P.; Weisenburger, D.D.; Linet, M.S. Lymphoma incidence patterns by who subtype in the united states, 1992-2001. Blood 2006, 107, 265-276. [CrossRef] [PubMed]

2. Effect of age on the characteristics and clinical behavior of non-hodgkin's lymphoma patients. The non-hodgkin's lymphoma classification project. Ann. Oncol. 1997, 8, 973-978.

3. Smith, A.; Crouch, S.; Howell, D.; Burton, C.; Patmore, R.; Roman, E. Impact of age and socioeconomic status on treatment and survival from aggressive lymphoma: A UK population-based study of diffuse large b-cell lymphoma. Cancer Epidemiol. 2015, 39, 1103-1112. [CrossRef] [PubMed]

4. Morrison, V.A.; Hamlin, P.; Soubeyran, P.; Stauder, R.; Wadhwa, P.; Aapro, M.; Lichtman, S. Diffuse large b-cell lymphoma in the elderly: Impact of prognosis, comorbidities, geriatric assessment, and supportive care on clinical practice. An international society of geriatric oncology (siog) expert position paper. J. Geriatr. Oncol. 2015, 6, 141-152. [CrossRef]

5. A predictive model for aggressive non-hodgkin's lymphoma. The international non-hodgkin's lymphoma prognostic factors project. N. Engl. J. Med. 1993, 329, 987-994.

6. Coiffier, B.; Lepage, E.; Briere, J.; Herbrecht, R.; Tilly, H.; Bouabdallah, R.; Morel, P.; Van Den Neste, E.; Salles, G.; Gaulard, P.; et al. Chop chemotherapy plus rituximab compared with chop alone in elderly patients with diffuse large-b-cell lymphoma. N. Engl. J. Med. 2002, 346, 235-242. [CrossRef]

7. Pfreundschuh, M.; Schubert, J.; Ziepert, M.; Schmits, R.; Mohren, M.; Lengfelder, E.; Reiser, M.; Nickenig, C.; Clemens, M.; Peter, N.; et al. Six versus eight cycles of bi-weekly chop-14 with or without rituximab in elderly patients with aggressive cd20+ b-cell lymphomas: A randomised controlled trial (ricover-60). Lancet Oncol. 2008, 9, 105-116. [CrossRef]

8. Habermann, T.M.; Weller, E.A.; Morrison, V.A.; Gascoyne, R.D.; Cassileth, P.A.; Cohn, J.B.; Dakhil, S.R.; Woda, B.; Fisher, R.I.; Peterson, B.A.; et al. Rituximab-chop versus chop alone or with maintenance rituximab in older patients with diffuse large b-cell lymphoma. J. Clin. Oncol. Off. J. Am. Soc. Clin. Oncol. 2006, 24, 3121-3127. [CrossRef]

9. Feugier, P.; Van Hoof, A.; Sebban, C.; Solal-Celigny, P.; Bouabdallah, R.; Ferme, C.; Christian, B.; Lepage, E.; Tilly, H.; Morschhauser, F; et al. Long-term results of the r-chop study in the treatment of elderly patients with diffuse large b-cell lymphoma: A study by the groupe d'etude des lymphomes de l'adulte. J. Clin. Oncol. Off. J. Am. Soc. Clin. Oncol. 2005, 23, 4117-4126. [CrossRef]

10. Tilly, H.; Gomes da Silva, M.; Vitolo, U.; Jack, A.; Meignan, M.; Lopez-Guillermo, A.; Walewski, J.; Andre, M.; Johnson, P.W.; Pfreundschuh, M.; et al. Diffuse large b-cell lymphoma (dlbcl): Esmo clinical practice guidelines for diagnosis, treatment and follow-up. Ann. Oncol. Off. J. Eur. Soc. Med. Oncol./ESMO 2015, 26 (Suppl. 5), v11-v125. [CrossRef]

11. Pfreundschuh, M.; Trumper, L.; Kloess, M.; Schmits, R.; Feller, A.C.; Rube, C.; Rudolph, C.; Reiser, M.; Hossfeld, D.K.; Eimermacher, H.; et al. Two-weekly or 3-weekly chop chemotherapy with or without etoposide for the treatment of elderly patients with aggressive lymphomas: Results of the nhl-b2 trial of the dshnhl. Blood 2004, 104, 634-641. [CrossRef] [PubMed]

12. Buske, C.; Hutchings, M.; Ladetto, M.; Goede, V.; Mey, U.; Soubeyran, P.; Spina, M.; Stauder, R.; Trneny, M.; Wedding, U.; et al. Esmo consensus conference on malignant lymphoma: General perspectives and recommendations for the clinical management of the elderly patient with malignant lymphoma. Ann. Oncol. 2017, 29, 544-562. [CrossRef] [PubMed] 
13. Sehn, L.H.; Berry, B.; Chhanabhai, M.; Fitzgerald, C.; Gill, K.; Hoskins, P.; Klasa, R.; Savage, K.J.; Shenkier, T.; Sutherland, J.; et al. The revised international prognostic index (r-ipi) is a better predictor of outcome than the standard ipi for patients with diffuse large b-cell lymphoma treated with r-chop. Blood 2007, 109, 1857-1861. [CrossRef] [PubMed]

14. Zhou, Z.; Sehn, L.H.; Rademaker, A.W.; Gordon, L.I.; Lacasce, A.S.; Crosby-Thompson, A.; Vanderplas, A.; Zelenetz, A.D.; Abel, G.A.; Rodriguez, M.A.; et al. An enhanced international prognostic index (nccn-ipi) for patients with diffuse large b-cell lymphoma treated in the rituximab era. Blood 2014, 123, 837-842. [CrossRef]

15. Morrison, V.A.; Hamlin, P.; Soubeyran, P.; Stauder, R.; Wadhwa, P.; Aapro, M.; Lichtman, S.M. Approach to therapy of diffuse large b-cell lymphoma in the elderly: The international society of geriatric oncology (siog) expert position commentary. Ann. Oncol. Off. J. Eur. Soc. Med. Oncol./ESMO 2015, 26, 1058-1068. [CrossRef]

16. Stauder, R.; Nosslinger, T.; Pfeilstocker, M.; Sperr, W.R.; Wimazal, F.; Krieger, O.; Valent, P. Impact of age and comorbidity in myelodysplastic syndromes. J. Natl. Compr. Cancer Netw. JNCCN 2008, 6, 927-934. [CrossRef]

17. Charlson, M.E.; Pompei, P.; Ales, K.L.; MacKenzie, C.R. A new method of classifying prognostic comorbidity in longitudinal studies: Development and validation. J. Chronic Dis. 1987, 40, 373-383. [CrossRef]

18. Asmis, T.R.; Ding, K.; Seymour, L.; Shepherd, F.A.; Leighl, N.B.; Winton, T.L.; Whitehead, M.; Spaans, J.N.; Graham, B.C.; Goss, G.D. Age and comorbidity as independent prognostic factors in the treatment of non small-cell lung cancer: A review of national cancer institute of Canada clinical trials group trials. J. Clin. Oncol. Off. J. Am. Soc. Clin. Oncol. 2008, 26, 54-59. [CrossRef]

19. Wieringa, A.; Boslooper, K.; Hoogendoorn, M.; Joosten, P.; Beerden, T.; Storm, H.; Kibbelaar, R.E.; Veldhuis, G.J.; van Kamp, H.; van Rees, B.; et al. Comorbidity is an independent prognostic factor in patients with advanced-stage diffuse large b-cell lymphoma treated with r-chop: A population-based cohort study. Br. J. Haematol. 2014, 165, 489-496. [CrossRef]

20. Kobayashi, Y.; Miura, K.; Hojo, A.; Hatta, Y.; Tanaka, T.; Kurita, D.; Iriyama, N.; Kobayashi, S.; Takeuchi, J. Charlson comorbidity index is an independent prognostic factor among elderly patients with diffuse large b-cell lymphoma. J. Cancer Res. Clin. Oncol. 2011, 137, 1079-1084. [CrossRef]

21. Lin, T.L.; Kuo, M.C.; Shih, L.Y.; Dunn, P.; Wang, P.N.; Wu, J.H.; Tang, T.C.; Chang, H.; Hung, Y.S. The impact of age, charlson comorbidity index, and performance status on treatment of elderly patients with diffuse large b cell lymphoma. Ann. Hematol. 2012, 91, 1383-1391. [CrossRef] [PubMed]

22. Morrison, V.A.; Hamilton, L.; Ogbonnaya, A.; Raju, A.; Hennenfent, K.; Galaznik, A. Treatment approaches for older and oldest patients with diffuse large b-cell lymphoma-Use of non-r-chop alternative therapies and impact of comorbidities on treatment choices and outcome: A humedica database retrospective cohort analysis, 2007-2015. J. Geriatr. Oncol. 2019, 11, 41-54. [CrossRef] [PubMed]

23. Sorror, M.L.; Maris, M.B.; Storb, R.; Baron, F.; Sandmaier, B.M.; Maloney, D.G.; Storer, B. Hematopoietic cell transplantation (hct)-specific comorbidity index: A new tool for risk assessment before allogeneic hct. Blood 2005, 106, 2912-2919. [CrossRef] [PubMed]

24. Kerbauy, D.M.; Chyou, F.; Gooley, T.; Sorror, M.L.; Scott, B.; Pagel, J.M.; Myerson, D.; Appelbaum, F.R.; Storb, R.; Deeg, H.J. Allogeneic hematopoietic cell transplantation for chronic myelomonocytic leukemia. Biol. Blood Marrow Transplant. J. Am. Soc. Blood Marrow Transplant. 2005, 11, 713-720. [CrossRef]

25. Sorror, M.L.; Sandmaier, B.M.; Storer, B.E.; Franke, G.N.; Laport, G.G.; Chauncey, T.R.; Agura, E.; Maziarz, R.T.; Langston, A.; Hari, P.; et al. Long-term outcomes among older patients following nonmyeloablative conditioning and allogeneic hematopoietic cell transplantation for advanced hematologic malignancies. JAMA 2011, 306, 1874-1883. [CrossRef]

26. Raimondi, R.; Tosetto, A.; Oneto, R.; Cavazzina, R.; Rodeghiero, F.; Bacigalupo, A.; Fanin, R.; Rambaldi, A.; Bosi, A. Validation of the hematopoietic cell transplantation-specific comorbidity index: A prospective, multicenter gitmo study. Blood 2012, 120, 1327-1333. [CrossRef]

27. Mian, M.; Wasle, I.; Gamerith, G.; Mondello, P.; Melchardt, T.; Jager, T.; Linkesch, W.; Fiegl, M. R-chop versus r-comp: Are they really equally effective? Clin. Oncol. (R. Coll. Radiol. (Gt. Br.)) 2014, 26, 648-652. [CrossRef]

28. Mian, M.; Augustin, F.; Kocher, F.; Gunsilius, E.; Willenbacher, W.; Zabernigg, A.; Zangerl, G.; Oexle, H.; Schreieck, S.; Schnallinger, M.; et al. A success story: How a single targeted-therapy molecule impacted on treatment and outcome of diffuse large b-cell lymphoma. Anticancer Res. 2014, 34, 2559-2564.

29. Cheson, B.D.; Pfistner, B.; Juweid, M.E.; Gascoyne, R.D.; Specht, L.; Horning, S.J.; Coiffier, B.; Fisher, R.I.; Hagenbeek, A.; Zucca, E.; et al. Revised response criteria for malignant lymphoma. J. Chin. Oncol. 2007, 25, 579-586. [CrossRef] 
30. Cheson, B.D.; Horning, S.J.; Coiffier, B.; Shipp, M.A.; Fisher, R.I.; Connors, J.M.; Lister, T.A.; Vose, J.; Grillo-López, A.; Hagenbeek, A.; et al. Report of an international workshop to standardize response criteria for non-hodgkin's lymphomas. J. Clin. Oncol. Off. J. Am. Soc. Clin. Oncol. 1999, 17, 1-14. [CrossRef]

31. Wasterlid, T.; Mohammadi, M.; Smedby, K.E.; Glimelius, I.; Jerkeman, M.; Bottai, M.; Eloranta, S. Impact of comorbidity on disease characteristics, treatment intent and outcome in diffuse large b-cell lymphoma: A Swedish lymphoma register study. J. Intern. Med. 2019, 285, 455-468. [CrossRef] [PubMed]

32. Hermet, E.; Cabrespine, A.; Guieze, R.; Garnier, A.; Tempescul, A.; Lenain, P.; Bouabdallah, R.; Vilque, J.P.; Frayfer, J.; Bordessoule, D.; et al. Autologous hematopoietic stem cell transplantation in elderly patients $(>/=$ 70 years) with non-hodgkin's lymphoma: A French society of bone marrow transplantation and cellular therapy retrospective study. J. Geriatr. Oncol. 2015, 6, 346-352. [CrossRef] [PubMed]

33. Caglayan, C.; Goldstein, J.S.; Ayer, T.; Rai, A.; Flowers, C.R. A population-based multistate model for diffuse large b-cell lymphoma-specific mortality in older patients. Cancer 2019, 125, 1837-1847. [CrossRef] [PubMed]

34. Saygin, C.; Jia, X.; Hill, B.; Dean, R.; Pohlman, B.; Smith, M.R.; Jagadeesh, D. Impact of comorbidities on outcomes of elderly patients with diffuse large b-cell lymphoma. Am. J. Hematol. 2017, 92, 989-996. [CrossRef]

35. Hamaker, M.E.; Prins, M.C.; Stauder, R. The relevance of a geriatric assessment for elderly patients with a haematological malignancy-a systematic review. Leuk. Res. 2014, 38, 275-283. [CrossRef]

36. Antic, D.; Jelicic, J.; Trajkovic, G.; Balint, M.T.; Bila, J.; Markovic, O.; Petkovic, I.; Nikolic, V.; Andjelic, B.; Djurasinovic, V.; et al. Is it possible to improve prognostic value of nccn-ipi in patients with diffuse large $b$ cell lymphoma? The prognostic significance of comorbidities. Ann. Hematol. 2018, 97, 267-276. [CrossRef]

37. Kwak, L.W.; Halpern, J.; Olshen, R.A.; Horning, S.J. Prognostic significance of actual dose intensity in diffuse large-cell lymphoma: Results of a tree-structured survival analysis. J. Clin. Oncol. Off. J. Am. Soc. Clin. Oncol. 1990, 8, 963-977. [CrossRef]

38. Pettengell, R.; Schwenkglenks, M.; Bosly, A. Association of reduced relative dose intensity and survival in lymphoma patients receiving chop-21 chemotherapy. Ann. Hematol. 2008, 87, 429-430. [CrossRef]

39. Liu, H.; Zhang, C.L.; Feng, R.; Li, J.T.; Tian, Y.; Wang, T. Validation and refinement of the age, comorbidities, and albumin index in elderly patients with diffuse large b-cell lymphoma: An effective tool for comprehensive geriatric assessment. Oncologist 2018, 23, 722-729. [CrossRef]

40. Eyre, T.A.; Martinez-Calle, N.; Hildyard, C.; Eyre, D.W.; Plaschkes, H.; Griffith, J.; Wolf, J.; Fields, P.; Gunawan, A.; Oliver, R.; et al. Impact of intended and relative dose intensity of r-chop in a large, consecutive cohort of elderly diffuse large b-cell lymphoma patients treated with curative intent: No difference in cumulative incidence of relapse comparing patients by age. J. Intern. Med. 2019, 285, 681-692. [CrossRef]

41. Goede, V.; Stauder, R. Multidisciplinary care in the hematology clinic: Implementation of geriatric oncology. J. Geriatr. Oncol. 2019, 10, 497-503. [CrossRef]

42. Peyrade, F.; Bologna, S.; Delwail, V.; Emile, J.F.; Pascal, L.; Ferme, C.; Schiano, J.M.; Coiffier, B.; Corront, B.; Farhat, H.; et al. Combination of ofatumumab and reduced-dose chop for diffuse large b-cell lymphomas in patients aged 80 years or older: An open-label, multicentre, single-arm, phase 2 trial from the lysa group. Lancet Haematol. 2017, 4, e46-e55. [CrossRef]

43. Peyrade, F.; Jardin, F.; Thieblemont, C.; Thyss, A.; Emile, J.F.; Castaigne, S.; Coiffier, B.; Haioun, C.; Bologna, S.; Fitoussi, O.; et al. Attenuated immunochemotherapy regimen (r-minichop) in elderly patients older than 80 years with diffuse large b-cell lymphoma: A multicentre, single-arm, phase 2 trial. Lancet Oncol. 2011, 12, 460-468. [CrossRef]

44. Soubeyran, P.; Terret, C.; Bellera, C.; Bonnetain, F.; Jean, O.S.; Galvin, A.; Chakiba, C.; Zwolakowski, M.D.; Mathoulin-Pelissier, S.; Rainfray, M. Role of geriatric intervention in the treatment of older patients with cancer: Rationale and design of a phase iii multicenter trial. BMC Cancer 2016, 16, 932. [CrossRef] [PubMed]

45. Mohile, S.G.; Dale, W.; Somerfield, M.R.; Schonberg, M.A.; Boyd, C.M.; Burhenn, P.S.; Canin, B.; Cohen, H.J.; Holmes, H.M.; Hopkins, J.O.; et al. Practical assessment and management of vulnerabilities in older patients receiving chemotherapy: Asco guideline for geriatric oncology. J. Clin. Oncol. Off. J. Am. Soc. Clin. Oncol. 2018, 36, 2326-2347. [CrossRef]

(C) 2020 by the authors. Licensee MDPI, Basel, Switzerland. This article is an open access article distributed under the terms and conditions of the Creative Commons Attribution (CC BY) license (http://creativecommons.org/licenses/by/4.0/). 